\title{
Tsunami effects on Coquimbo Bay wetland water-bird species composition, associated with the 2015 Mw8.4 Illapel earthquake (northern Chile)
}

\author{
César Chávez-Villavicencio ${ }^{1,2}$, Elier Tabilo-Valdivieso ${ }^{1,2,3}$ \& Christian Jofré-Pérez ${ }^{1,3,4}$ \\ ${ }^{1}$ Programa de Doctorado en Biología y Ecología Aplicada, Consorcio Universidad Católica del Norte \\ y Universidad de La Serena, Chile \\ ${ }^{2}$ Centro Neotropical de Entrenamiento en Humedales (www.centroneotropical.org) \\ ${ }^{3}$ Departamento de Biología e Instituto de Ecología y Biodiversidad, Facultad de Ciencias \\ Universidad de La Serena, La Serena, Chile \\ ${ }^{4}$ Departamento Disciplinario de Ciencias Básicas e Informática, Campus San Felipe \\ Universidad de Playa Ancha, San Felipe, Chile \\ Corresponding author: César Chávez-Villavicencio (cchavez@ucn.cl)
}

\begin{abstract}
On September 16, 2015, an earthquake occurred in Chile, causing a tsunami (T16S) that impacted Coquimbo Bay, where the Punta Teatinos, Elqui River Mouth, and El Culebrón wetlands are located. Changes in the flat topography produced by the T16S in these wetlands are described using Google Earth Pro v. 7.3.2.5491 and in waterbird richness, with data obtained from eBird. The richness of the accumulated species $(S=43)$, the similarity of the richness (analysis of conglomerates and similarity index of Sorensen) and differences between means of waterbird richness before and after T16S were analyzed statistically. The similarity in the composition of water birds before and after T16S were, Punta Teatinos (0.83), Mouth of the Elqui River (0.86) and El Culebrón (0.91), the latter was the most affected in its flat topography but showed higher similarity before and after T16S. No statistical differences in the mean of waterbird richness were found before and after T16S. The three wetlands were highly resilient. The original flat topography, the vegetation structure and the water bird richness recovered in a year. It is considered that water birds and these wetlands are resilient to disturbances.
\end{abstract}

Keywords: coastal wetland; disturbance; ecosystem; bird; seaquake; wetland; resilience

The effect of earthquakes and tsunamis on wildlife is poorly documented. Usually, this is because these kinds of events cannot be predicted; although the accurate forecast of the location and size of events is becoming a possibility (Geller et al., 1997; Schorlemmer \& Wiemer, 2005). Coastal wetlands are considered highly resilient systems to withstand the effects of storms and tsunamis. They recover relatively quickly and protect coastal locations from flooding (Ramsar Wetlands Convention, 2017; Grenfell et al., 2019). One of the few efforts to evaluate these effects showed that the earthquake and tsunami of February 27, 2010 with an epicenter in Cauquenes ( $35^{\circ} 54^{\prime} \mathrm{S}, 72^{\circ} 43^{\prime} \mathrm{W}$ ), produced significant and lasting changes in the physical and ecological attributes of the sandy beaches on the coast of Maule Region ( $35^{\circ} 18^{\prime}$ S, $72^{\circ} 24^{\prime} \mathrm{W}$ ) and Biobío Region
(36 49'S, 739'W) (Jaramillo et al., 2012). The invertebrate species characteristic of the intertidal zones was affected in their distribution and abundance; some species responded quickly in their recovery, while others presented a slow recovery within the first year after the event (Jaramillo et al., 2012).

Similar effects were observed in Tubul-Raqui wetland $\left(37^{\circ} 14^{\prime} \mathrm{S}, 73^{\circ} 26^{\prime} \mathrm{W}\right)$. A large part of that wetland had a vertical water level increase of approximately $1.6 \mathrm{~m}$ above the mean sea level, generating strong modifications in the aquatic component of the wetland, especially in the area of intertidal marshes that were partially dried (Valdovinos et al., 2010). The estuarine crustacean Hemigrapsus crenulatus experienced high mortality due to the natural trawling of the seafloor. The mortality of some water birds increased,

Corresponding editor: Sergio Palma 
which in turn increased the population of carrion birds in the area. The mortality rate of certain barnacles Elminius kingie and estuarine crab $H$. crenulatus also increased. There was also significant damage to the vegetation of the "cordgrasses" (Spartina densiflora). Although it suffered severe damage in the 2010 earthquake, it has characteristics that allow it to recover and stay within the country's most important coastal wetlands; because the "cordgrasses" were able to recover they were able to provide nesting and refuge sites for numerous resident, and migratory bird species (Valdovinos et al., 2010).

The same tsunami also had a significant impact on

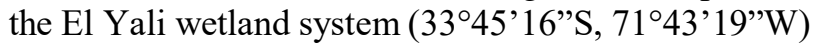
where it flooded 840 ha of the coastal zone, of which 213 ha correspond to the Ramsar Site and El Yali National Reserve. The flood entered the continent approximately $1,400 \mathrm{~m}$ in the southern sector of the Albufera, $830 \mathrm{~m}$ in the northern sector of the same coastal lagoon, 200 $m$ in the beach located to the north of the National Reserve and 2,000 $\mathrm{m}$ in the dunes and El Yali Estuary. Evidence was found that the tsunami wave traced up to $5.2 \mathrm{~km}$ into the estuary. The number of bird species was mainly affected in May and December 2010, when 50\% of the species disappeared but were replaced by $20 \%$ of new species as of June 2011. The number of individuals in December 2010 began to experience a recovery in several species. The monthly counts made by the Corporación Nacional Forestal (CONAF) in the Reserve, found that the bird's richness and their abundance recovered after 2010 (Contreras-López, 2014).

On 16 September, 2015, an earthquake of magnitude 8.4 , on the Richter scale, occurred in the Coquimbo Region (northern Chile), with an epicenter located at $31^{\circ} 38^{\prime} \mathrm{S}, 71^{\circ} 44^{\prime} \mathrm{W}$, at 19:54 h local time (Heidarzadeh et al., 2016; Satake \& Heidarzadeh, 2017). This event triggered a tsunami (T16S) that caused damages and floods on the northern coast of Chile, mainly in the Coquimbo Bay, where Punta Teatinos $\left(29^{\circ} 49^{\prime} \mathrm{S}, 71^{\circ} 17^{\prime} \mathrm{W}\right)$, Elqui River Mouth $\left(29^{\circ} 53^{\prime} \mathrm{S}, 7^{\circ} 16^{\prime} \mathrm{W}\right)$ and El Culebrón (29 57'S, $71^{\circ} 19^{\prime} \mathrm{W}$ ), wetlands are located (Contreras-López et al., 2016; Abad et al., 2017). According to mareograph data, the first wave reached the coast of Coquimbo only 20 min after the earthquake, with a maximum height of $0.85 \mathrm{~m} 22 \mathrm{~min}$ later; a second wave arrived with a height of $4.3 \mathrm{~m}$ causing the first damages in the littoral and the city. The last wave arrived $35 \mathrm{~min}$ after the earthquake and was the highest and most damaging, reaching $4.68 \mathrm{~m}$ in height. The waves entered more than $950 \mathrm{~m}$ at the Elqui River Mouth and almost $700 \mathrm{~m}$ in the El Culebrón wetland (Abad et al., 2017), and the reach of the Punta Teatinos wetland is unknown. Preliminary observations in El Culebrón wetland, the morning of September 17, 2015 (one day after T16S), allowed establishing that the wetland was utterly modified in its flat topography and the water birds that generally inhabit the wetland (Families Anatidae, Podicipedidae, Rallidae, Charadriidae, Haematopodidae, Recurvirostridae, Scolopacidae, Rynchopidae, Phalacrocoracidae, Ardeidae, and Threskiornithidae), had disappeared; added to the background, this observation led to propose the question of the effect of the T16S on the waterbird richness of the three wetlands of the Coquimbo Bay. Therefore, the objective was to determine the changes in the flat topography and waterbird richness produced by the T16S in Punta Teatinos, Elqui River Mouth, and El Culebrón wetlands.

Punta Teatinos, Elqui River Mouth and El Culebrón are three coastal wetlands located in the Coquimbo Bay, which is shared by the cities of La Serena and Coquimbo (Fig. 1). Punta Teatinos is a wetland of natural origin located at the north end of the Coquimbo Bay with approximately 69 ha. It receives mixed hydric supply from the El Romeral Stream in a seasonal way and contributes a considerable amount of nutrients and sediments to the wetland; it also receives marine supply at high tide. It is a lagoon where the emergent vegetation predominates like lesser bulrush (Typha angustifolia) and California bulrush (Scirpus californicus). This wetland has high social significance for the local community, especially in the summer months, when it is used for recreational activities (Tabilo et al., 2016). Elqui River Mouth corresponds to the northernmost river in the semi-arid zone of Chile and represents the southern limit of the Atacama Desert. At the mouth, there is a lagoon of approximately 113 ha that pours its water into the sea. Lesser bulrush and California bulrush are the emergent vegetation dominant. Currently, it is under pressure from anthropic activities such as recreational and city expansion (Tabilo et al., 2016). El Culebrón is the mouth to the sea of a permanent riverine system. It is located at the southern end of the Coquimbo Bay with approximately 60 ha. It presents conditions of permanent drainage of the water that comes from the Pan de Azúcar basin, although it also receives marine inputs in the high tide which turns its waters brackish. The mouth has a complex morphology due to the high dynamism of the waters. This wetland has been modified in its channel by high anthropic pressure and growth of the city (Tabilo et al., 2016).

Before and after T16S images were obtained from free software, Google Earth Pro v.7.1.7.2606 (Google Earth, 2018). Immediate images before and after the T16S event were used. Then, the images corresponding to one year after the event were used for the comparison. Changes in the flat topography of the wetlands were 


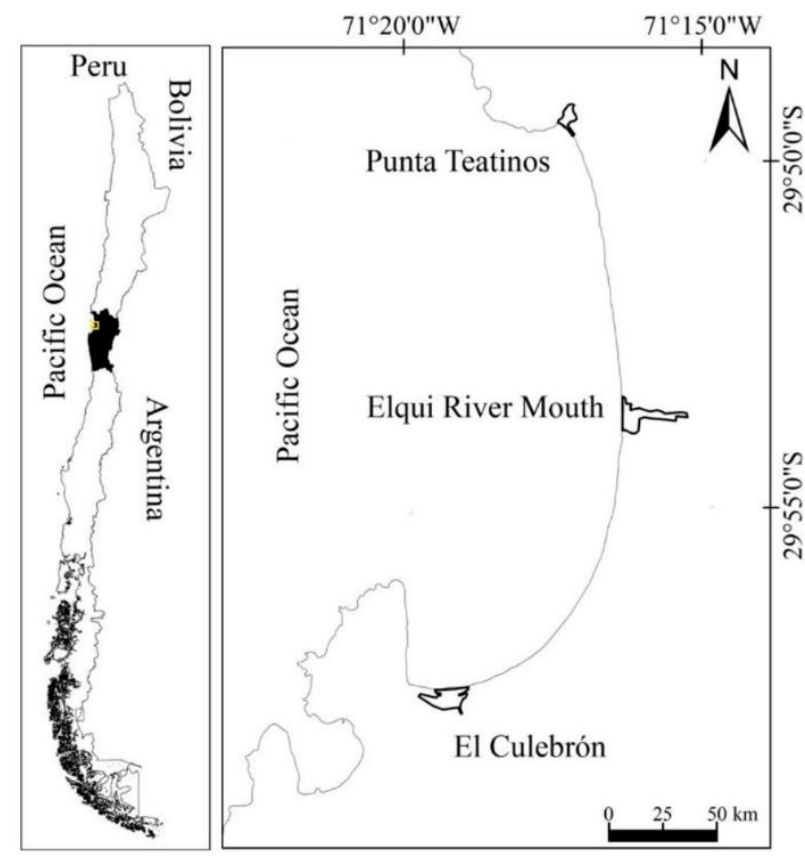

Figure 1. Location of Punta Teatinos, Elqui River Mouth and El Culebrón wetlands in Coquimbo Bay, Chile.

analyzed through a comparative description of the images in the three proposed times. Impact over the vegetation was determined by direct observation before and after of the T16S until October 2016. Waterbird richness data from before and after T16S were requested from the eBird database platform (Sullivan $e t$ al., 2009). Species presence data were considered in each wetland from January to August 2015, to build the pre-event bird richness, and from October 2015 to December 2016, to build post-event richness. If some wetland presented zero records for a month, this month was discarded for the three wetlands. It only worked with the registration of waterbird because this group was considered the most susceptible to being affected by the tsunami. Because different bird observers collected this data, in order to minimize errors, for the analysis it was considered the accumulated waterbird species richness both before and after T16S, and the similarity was evaluated with a hierarchical clustering analyses using Jaccard distance, single linked and 200 resampling for node significance using software PAST v.3.16 (Hammer et al., 2001). This analysis was complemented with qualitative Sorensen similarity index (Moreno, 2001) because it relates the number of species in common with the arithmetic mean of the species in both cases (Magurran, 1988). Sorensen similarity index was calculated with software EstimateS v.9.1.0 (Colwell, 2013). Finally, multiple comparisons of means (Tukey contrasts) with R ( R core team, 2018) were made to evaluate the previous and posterior differences between the mean accumulated monthly waterbird richness for each wetland.

The evaluated images showed that the wetland of Punta Teatinos did not suffer variation in its flat topography, which remained stable resisting the irruption of the tsunami (Fig. 2). Elqui River Mouth was affected by the irruption of the tsunami waves (Fig. 2 ). The seawater that entered left a deposit of sand of approximately one hectare in the south bank of the river, which caused the loss of part of the body of water (Fig. 2). It was expected that this sand deposit would be removed by the outflow of the river to the sea; however, a year after the tsunami, part of the sand deposit, with an area of approximately 0.3 ha was still observed (Fig. 2). This deposit of sand usually disappears when the river presents significant floods but reappears when these floods diminish. Images reviewed before July 2015 did not show the sand deposit. The most impacted wetland in its flat topography was El Culebrón (Fig. 2). The sector of the sandy beach where the wetland flows into the sea was considerably reduced. Taking as a reference to the bridge that crosses the wetland (Del Mar Avenue Bridge), the distance to the shoreline before the T16S was approximately $200 \mathrm{~m}$ (Fig. 2). After T16S, the sea joined the wetland leaving a distance between the bridge and the shoreline of $80 \mathrm{~m}$ (Fig. 2). In October 2016, the distance between the bridge and the shoreline was $180 \mathrm{~m}$ (Fig. 2). In July 2015, before the T16S, the body of water between the Railway Bridge and the Del Mar Avenue Bridge had a surface of 1.6 ha. In September 2016, after the T16S, the body of water reached $1.8 \mathrm{ha}$, and that surface was maintained in October 2016. Also, it can be seen that before the T16S, the wetland shore presented vegetation composed mainly of lesser bulrush, California Bulrush and herbaceous, much of this vegetation (lesser bulrush and California bulrush mainly) was removed and crushed by the entrance of water from the sea. In October 2016, this vegetation that was removed and crushed appeared to be recovering. At present, the vegetation on the shore of the body of water is in recovery. The review of the eBird platform database (Sullivan et al., 2009) showed that both before and after the T16S, there was a water bird richness of 43 species among the three wetlands. These species were distributed in 24, 33 and 35 species in Punta Teatinos, Elqui River Mouth and El Culebrón wetlands, respectively, before T16S; and 29, 41 and 35 species in the three wetlands, respectively, after T16S. At Punta Teatinos, 22 species registered before T16S were re-registered after the event, at the Elqui River Mouth and El Culebrón, 32 species were recorded both before and after (Table 1). 


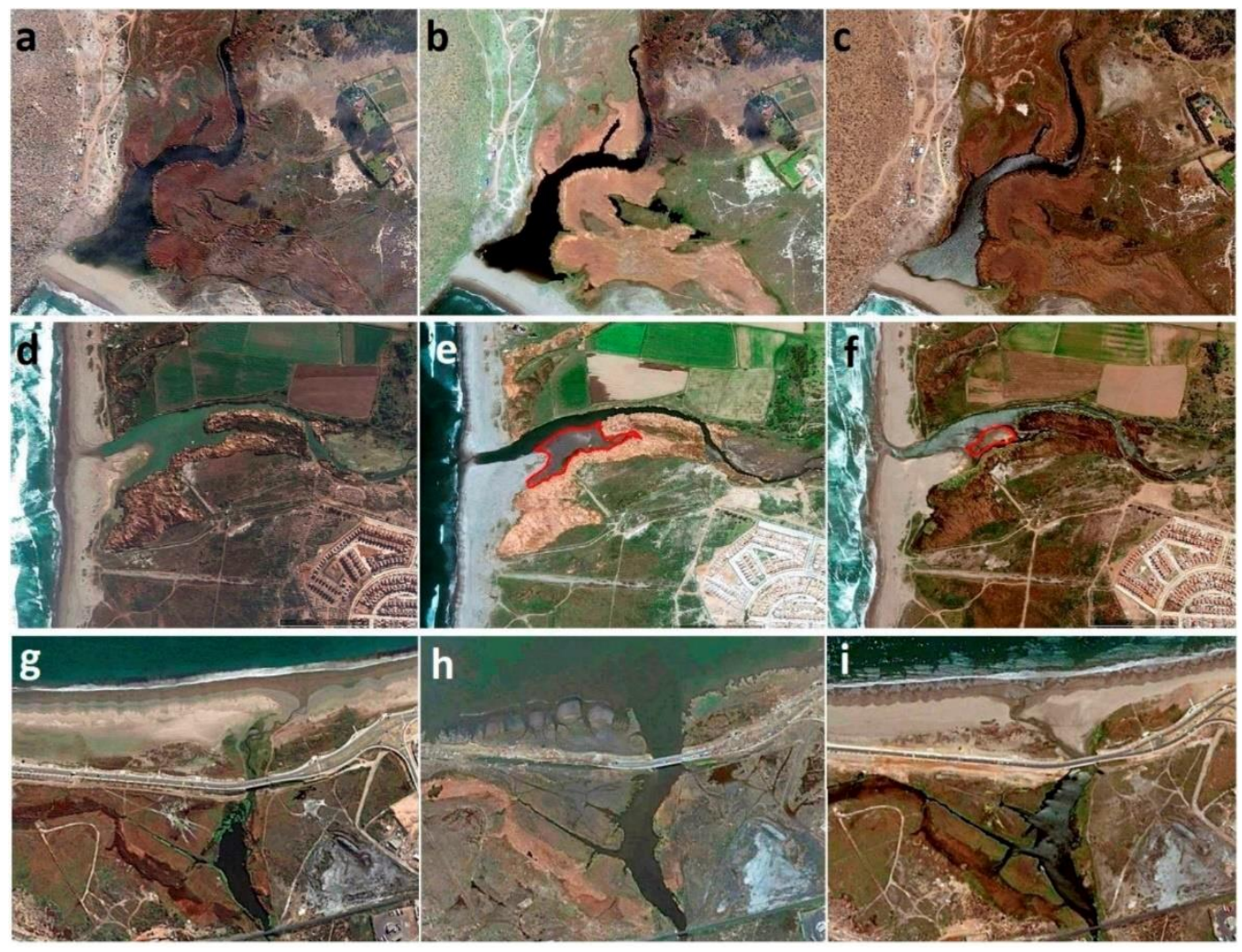

Figure 2. Upper: Punta Teatinos wetland. a) July 2015, b) September 2015 after T16S, c) October 2016: it is observed that the wetland remained without drastic changes. Middle: Elqui River Mouth. d) July 2015, e) September 2015 after T16S: in the red polygon the sand deposit is observed, f) October 2016: In the red polygon the remaining sand deposit is observed. Lower: El Culebrón wetland. g) July 2015: shore vegetation, broad sandy beach and narrow body of water are observed, h) September 2015 after T16S: loss of vegetation, increase in the surface of the body of water and decrease of the sandy beach is observed, i) October 2016: the recovery of the sandy beach and apparently of the vegetation is appreciated although the body of water maintained its surface.

The clustering analysis confirmed a high similarity in the waterbird richness composition between the before and after T16S, in the three wetlands, and between the after T16S of the Elqui River Mouth with the before and after the T16S of the El Culebrón (Fig. $3)$. Also, the Sorensen similarity index established that the Punta Teatinos wetland had $83 \%$ similarity in waterbird richness composition between before and after T16S. Netta peposaca was registered after T16S between December 2015 and January 2016, Charadrius modestus was recorded between April and July 2016, and there were no more reports in the database consulted. Laterallus jamaicensis in addition to the posterior record to the T16S was also recorded in July 2011, September 2012 and May 2016, likewise Phalacrocorax gaimardi was recorded on September 2006, January 2010 and January 2016. The Elqui River Mouth had a similarity of $86 \%$ in waterbird richness composition between before and after T16S. Cygnus melancoryphus was only recorded after T16S in June and July 2016. There is no record in eBird (Sullivan $e t$ $a l ., 2009)$ for the pre-event. The other seven species recorded after the event also present records by January 2015. El Culebrón was the wetland with the highest similarity between before and after the event despite being the most affected by the T16S. The similarity reached $91 \%$ and the waterbird species richness of both before and after was the same ( 35 species). No species were recorded exclusively after T16S. Multiple comparisons of means (Tukey contrasts) does not find differences between before -after means of accumulated bird richness (Fig. 4). Means differences between before- after of waterbird richness in Punta Teatinos was 1 (CI 95\% -7-10, $P=0.99$ ), Elqui River Mouth was 4 (CI 95\% -3-12, $P=0.60)$ and El Culebrón was 4 (CI $95 \%-4-12, P=0.69)$.

Coastal wetlands are highly productive systems; besides being ecosystems recognized for their importance at a global level (Babinger, 2002), they fulfill functions of sediment control, discharge of groundwater and protection of coastal zones (Bó \& Malvárez, 1999). In general terms, wetlands are considered systems with high resilience (Carpenter \& Cottingham, 1997). The visual analysis of the images 
Table 1. List of waterbird richness in Punta Teatinos, Elqui River Mouth and El Culebrón wetlands, before and after T16S. 1: presence, 0 : absence.

\begin{tabular}{|c|c|c|c|c|c|c|}
\hline \multirow{2}{*}{ Species } & \multicolumn{2}{|c|}{ Punta Teatinos } & \multicolumn{2}{|c|}{ Elqui River Mouth } & \multicolumn{2}{|c|}{ El Culebrón } \\
\hline & Before & After & Before & After & Before & After \\
\hline Cygnus melancoryphus & 0 & 0 & 0 & 1 & 0 & 0 \\
\hline Coscoroba coscoroba & 0 & 0 & 0 & 1 & 0 & 0 \\
\hline Anas sibilatrix & 1 & 1 & 0 & 1 & 1 & 1 \\
\hline Anas flavirostris & 0 & 0 & 1 & 1 & 1 & 1 \\
\hline Anas georgica & 1 & 1 & 1 & 1 & 1 & 1 \\
\hline Anas cyanoptera & 1 & 1 & 1 & 1 & 1 & 1 \\
\hline Anas platalea & 0 & 0 & 0 & 1 & 1 & 0 \\
\hline Netta peposaca & 0 & 1 & 0 & 0 & 0 & 0 \\
\hline Oxyura vittata & 1 & 1 & 1 & 1 & 0 & 1 \\
\hline Rollandia rolland & 1 & 1 & 1 & 1 & 1 & 1 \\
\hline Podilymbus podiceps & 1 & 1 & 1 & 1 & 1 & 1 \\
\hline Podiceps major & 0 & 1 & 1 & 1 & 1 & 1 \\
\hline Podiceps occipitalis & 0 & 0 & 1 & 0 & 1 & 1 \\
\hline Laterallus jamaicensis & 0 & 1 & 1 & 1 & 0 & 0 \\
\hline Porphyriops melanops & 0 & 1 & 1 & 1 & 1 & 1 \\
\hline Pardirallus sanguinolentus & 1 & 1 & 1 & 1 & 0 & 1 \\
\hline Gallinula galeata & 1 & 1 & 0 & 1 & 1 & 1 \\
\hline Fulica armillata & 1 & 1 & 1 & 1 & 1 & 1 \\
\hline Fulica rufifrons & 1 & 1 & 1 & 1 & 1 & 1 \\
\hline Fulica ardesiaca & 0 & 0 & 0 & 1 & 0 & 0 \\
\hline Fulica leucoptera & 1 & 1 & 1 & 1 & 1 & 1 \\
\hline Vanellus chilensis & 1 & 1 & 1 & 1 & 1 & 1 \\
\hline Charadrius semipalmatus & 0 & 0 & 1 & 1 & 1 & 1 \\
\hline Charadrius nivosus & 1 & 1 & 1 & 1 & 1 & 0 \\
\hline Charadrius collaris & 1 & 1 & 1 & 1 & 1 & 1 \\
\hline Charadrius falklandicus & 0 & 0 & 1 & 1 & 0 & 1 \\
\hline Charadrius modestus & 0 & 1 & 0 & 1 & 1 & 1 \\
\hline Haematopus palliatus & 1 & 1 & 1 & 1 & 1 & 1 \\
\hline Haematopus ater & 1 & 1 & 1 & 1 & 1 & 0 \\
\hline Himantopus mexicanus & 1 & 1 & 1 & 1 & 1 & 1 \\
\hline Gallinago paraguaiae & 1 & 0 & 1 & 1 & 1 & 1 \\
\hline Rynchops niger & 1 & 1 & 1 & 1 & 1 & 1 \\
\hline Phalacrocorax gaimardi & 0 & 1 & 0 & 1 & 1 & 1 \\
\hline Phalacrocorax brasilianus & 1 & 1 & 1 & 1 & 1 & 1 \\
\hline Phalacrocorax bougainvillii & 1 & 1 & 1 & 1 & 1 & 1 \\
\hline Ixobrychus involucris & 0 & 0 & 1 & 1 & 1 & 1 \\
\hline Nycticorax nycticorax & 1 & 0 & 1 & 1 & 1 & 1 \\
\hline Bubulcus ibis & 0 & 1 & 1 & 1 & 1 & 1 \\
\hline Ardea cocoi & 0 & 0 & 1 & 1 & 1 & 1 \\
\hline Ardea alba & 1 & 1 & 1 & 1 & 1 & 1 \\
\hline Egretta thula & 1 & 1 & 1 & 1 & 1 & 1 \\
\hline Egretta caerulea & 0 & 0 & 1 & 1 & 1 & 1 \\
\hline Plegadis chihi & 0 & 0 & 0 & 1 & 1 & 1 \\
\hline Total richness & 24 & 29 & 33 & 41 & 35 & 35 \\
\hline
\end{tabular}

obtained from Google Earth Pro v.7.3.2.5491 showed that the Punta Teatinos wetland was resistant and responded without changing in its physical attributes to the T16S. The Elqui River Mouth is a resilient wetland, although the sand beach that separates the body of water from the sea was not altered after a year, this still shows the sand deposit left by the T16S that could not be removed by the hydric dynamics of the river. In contrast, El Culebrón showed a high resilience considering that it was the wetland most affected by the 


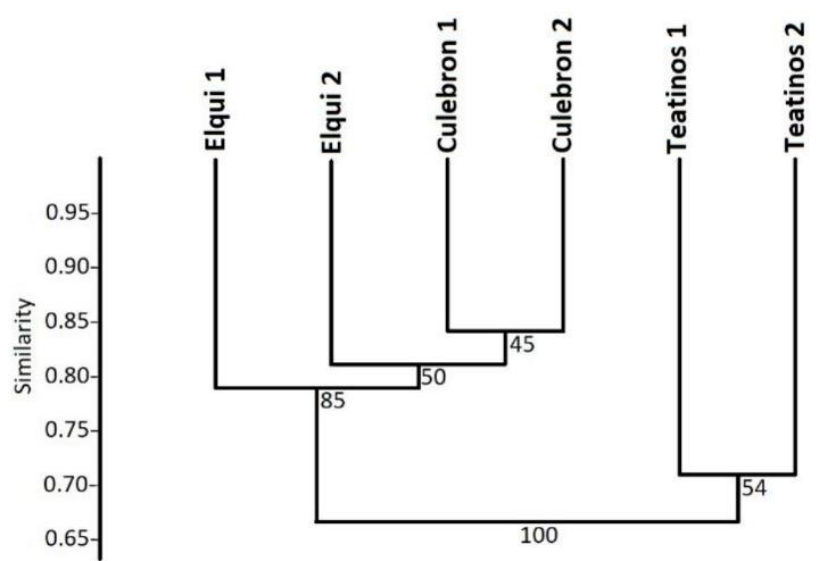

Figure 3. Dendrogram single method, Jaccard distance. The graph shows the closeness between the before and after T16S in the waterbird richness composition of each wetland. 1: Before T16S, 2: after T16S.

tsunami, although the body of water increased its surface by 0.2 ha. These results coincide with the rapid recovery of the El Yali wetland (Contreras-López, 2014). However, it stands out the fact that the T16S produced waves up to $4.68 \mathrm{~m}$ in height (Abad et al., 2017), while in February 2010 the Yali received waves up to $1.5 \mathrm{~m}$ in height (Contreras-López, 2014). El Culebrón began to show signs of recovery in its physical attributes in December 2015, according to the images of Google Earth Pro, the distance between the Del Mar Avenue Bridge and the shoreline of the sea was already $135 \mathrm{~m}$, and the beach was starting to recover. These results contribute to the affirmation that coastal wetlands are highly resilient in the time (Ramsar Wetlands Convention, 2017; Grenfell et al., 2019).

The vegetation of El Culebrón began to recover after January of 2016. The lesser bulrush and California bulrush crushed by the passage of the waves resumed its normal position, and the herbaceous vegetation was practically unaffected as in Punta Teatinos and the Elqui River Mouth. This same result was observed in the El Yali (Contreras-López, 2014), which would confirm that coastal wetland vegetation recovers rapidly after extreme events such as a tsunami. In the case of the waterbird richness, it was not possible to establish when it began to recover. Direct observations established that on the day after the tsunami, there was no water bird in El Culebrón, and the behavior in the other wetlands studied was unknown. However, in all three wetlands, waterbird richness was recovered before the following year. According to the eBird data (Sullivan et al., 2009), Punta Teatinos already recorded 16 waterbird species in October 2015, while 24 waterbird species were recorded in the Elqui River Mouth. El Culebrón, which was the most affected wetland, recorded 14 waterbird species in October 2015. Both Punta Teatinos and the Elqui River Mouth

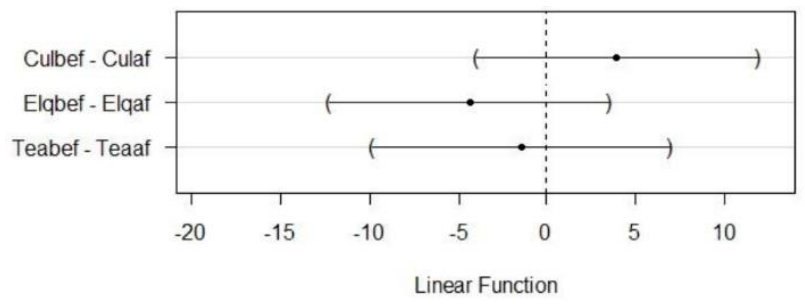

Figure 4. 95\% confidence intervals of the difference in means of waterbird species richness between before and after T16S. Cul: El Culebrón, Elq: Elqui River Mouth, Tea: Punta Teatinos, bef: before, af: after.

increased their waterbird richness the next year. In the case of El Culebrón, the waterbird richness was maintained, but the waterbird richness presented three species that were registered before January 2015. Frequently, bird richness is used as an indicator of ecosystem health, especially in wetlands (Ogden et al., 2014). Under this criterion, clustering analysis and similarities above $80 \%$, it can indicate that these three wetlands recovered healthily after a catastrophic event such as T16S. In the wetlands of Coquimbo Bay, the waterbird richness remained in similar conditions before and after the T16S; it is postulated that it was because of the high resilience of these wetlands to the disturbances without altering its structure and functionality (Holling, 1973). Resilience is a characteristic of coastal wetlands because despite resisting disturbances, they recover quickly (Ramsar Wetlands Convention, 2017; Grenfell et al., 2019). In addition, coastal wetlands resist disturbances such as tsunamis, storm surges and temps, all geophysical mechanisms that articulate elements that allow the coexistence of various species, which would not exist in the absence of these disturbances (Roxburgh et al., 2004).

\section{ACKNOWLEDGMENTS}

We want to thank Marcelo Rivadeneira and Moisés Aguilera for reviewing the manuscript, comments, and statistical support. Special thanks to anonymous reviewers for providing valuable suggestions on this manuscript. CJP is grateful for a CONICYT Scholarship No21150472 that allow him to pursue a Ph.D.'s program at the University of La Serena.

\section{REFERENCES}

Abad, M., Izquierdo, T., Lock, S., Rojas, D. \& Fritis, E. 2017. Geomorphic impact of the 16 S 2015 tsunami event in the Coquimbo Bay (northern Chile). Geophysical Research Abstracts, 19: 10241.

Babinger, F. 2002. La creciente importancia medioambiental de los humedales a modo de recensión bibliográfica. Observatorio Medioambiental, 5: 333-347. 
Bó, R. \& Malvárez, A. 1999. Las inundaciones y la biodiversidad en humedales. Un análisis del efecto de eventos extremos sobre la fauna silvestre. In: Malvárez, A.I. (Ed.). Tópicos sobre humedales subtropicales y templados de Sudamérica. Oficina Regional de Ciencia y Tecnología de la UNESCO para América Latina y el Caribe, ORCYT, Montevideo, pp. 140-161.

Carpenter, S.R. \& Cottingham, K.L. 1997. Resilience and restoration of lakes. Conservation Ecology 1(1): 2. [http://www.consecol.org/vol1/iss1/art2/]. Reviewed: April 5, 2017.

Colwell, R.K. 2013. EstimateS: Statistical estimation of species richness and shared species from samples. Version 9. [http://purl.oclc.org/estimates]. Reviewed: April 12, 2017.

Connell, J.H. 1978. Diversity in tropical rain forest and coral reefs. Science, 199: 1302-1310.

Contreras-López, M. 2014. Efectos del terremoto y tsunami del 27 de febrero de 2010 en la Reserva Nacional El Yali. Anales Museo de Historia Natural de Valparaíso, 27: 79-92.

Contreras-López, M., Winckler, P., Sepúlveda, I., Andaur-Álvarez, A., Cortés-Molina, F., Guerrero, C., Mizobe, C., Igualt, F., Breuer, W., Beyá, J., Vergara, H. \& Figueroa-Sterquel, R. 2016. Field survey of the 2015 Chile tsunami with emphasis on coastal wetland and conservation areas. Pure and Applied Geophysics, 173: 349-367.

Geller, D.D., Jackson, R.J., Kagan, Y.Y. \& Mulargia, F. 1997. Earthquake cannot be predicted. Science, 275: 1616-1617.

Google Earth. 2018. Google Earth Pro v.7.3.2.5491. [http://www.earth.google.com]. Reviewed: August 20, 2018.

Grenfell, S.E., Fortune, F., Manphoka, M.F. \& Sanderson, N. 2019. Coastal wetland resilience to climate change: modeling ecosystem response to rising sea level and salinity in a variable climate. Anthropocene Coasts, 2: 1-20. doi: 10.1139/anc-2018-0004

Hammer, Ø., Harper, D.A.T. \& Ryan, P.D. 2001. PAST: Paleontological statistics software package for education and data analysis. Palaeontologia Electronica, 4(1): 9 pp.

Heidarzadeh, M., Murotani, S. Satake, K., Ishib, T. \& Gusman, A.R. 2016. Source model of the 16 September 2015 Illapel, Chile, Mw8.4 earthquake based on teleseismic and tsunami data. Geophysical Research Letters, 43: 643-650. doi:10.1002/2015GL 067297.
Holling, C.S. 1973. Resilience and stability of ecological systems. Annual Review of Ecology, Evolution, and Systematics, 4: 1-23.

Jaramillo, E., Dugan, J.E., Hubbard, D.M., Melnick, D., Manzano, M., Duarte, C., Campos, C. \& Sánchez, R. 2012. Ecological implications of extreme events: footprints of the 2010 earthquake along the Chilean coast. Plos One, 7(5): e35348.

Magurran, A.E. 1988. Ecological diversity and its measurement. Princeton University Press, New Jersey.

Moreno, C.E. 2001. Métodos para medir la biodiversidad. M\&T: Manuales y Tesis SEA, vol. 1, Zaragoza.

Ogden, J.C., Baldwin, J.D., Bass, O.L., Browder, J.A., Cook, M.I., Frederick, P.C., Frezza, P.E., Galvez, R.A., Hodgson, A.B., Meyer, K.D., Oberhofer, L.D., Paul, A.F., Fletcher, P.J., Davis, S.M. \& Lorenz, J.J. 2014. Waterbirds as indicators of ecosystem health in the coastal marine habitats of southern Florida: 1. Selection and justification for a suite of indicator species. Ecological Indicators, 44: 148-163.

Ramsar Wetlands Convention. 2017. Los humedales: una protección natural frente a los desastres. Ficha informativa 9. [http://www.ramsar.org/sites/default/ files/fs_9_drr_esp_30j.pdf]. Reviewed: March 18, 2017.

R Core Team. 2018. R: a language and environment for statistical computing. R Foundation for Statistical Computing. [https://www.R-project.org/]. Reviewed: May 13, 2018.

Roxburgh, S.H., Shea, K. \& Wils, J.B. 2004. The intermediate disturbance hypothesis. Patch dynamics and mechanisms of species coexistence. Ecology, 85(2): 359-371.

Satake, K. \& Heidarzadeh, M. 2017. A review of source models of the 2015 Illapel, Chile earthquake and insights from tsunami data. Pure and Applied Geophysics, 174: 1-9. doi: 10.1007/s00024-016-1450-5.

Schorlemmer, D. \& Wiemer, S. 2005. Earth science: microseismicity data forecast rupture area. Nature, 434(7037): 1086.

Sullivan, B.L., Wood, C.L., Iliff, M.J., Bonney, R.E., Fink, D. \& Kelling, S. 2009. eBird: a citizen-based bird observation network in the biological sciences. Biological Conservation, 142: 2282-2292.

Tabilo, E., Burmeister, J., Chávez-Villavicencio, C. \& Zöckler, C. 2016. Humedales y aves migratorias en la costa árida del Pacifico sudamericano. Etapa I: evaluación ecológica rápida. Centro Neotropical de Entrenamiento en Humedales. Mamfred-HermsenStiftung, Bremen.

United States Geological Survey (USGS). 2015. Earthquake Hazard Program. M 8.3-48 km W of Illapel, Chile. [http://earthquake.usgs.gov/earthquakes/ 
eventpage/us20003k7a\#general_summary]. Reviewed: June 5, 2017.

Received: 29 October 2018; Accepted: 1 July 2019
Valdovinos, C., Muñoz, M., Sandoval, N., Vásquez, D. \& Olmos, V. 2010. Desastres naturales y biodiversidad: el caso del humedal costero Tubul-Raqui. Sociedad Hoy, 19: 33-51. 